\title{
Crossbreeding experiment with mixed semen of boars of different breeds
}

\author{
Elsi Ettala \\ Agricultural Research Centre, Department of Animal Husbandry
}

Received September 17, 1973

\begin{abstract}
Sows of the Finnish Landrace and Yorkshire breeds ( $\mathrm{L}$ and $\mathrm{Y}$ ) were artificially inseminated with mixed semen of Finnish Landrace and Yorkshire boars. Purebred and crossbred progeny were identified by blood group testing. The pairs of boars were selected to be as identical as possible in regard to semen quality.

Mixing of the two diluted semen fractions did not affect unfavourably the viability and motility of the sperm. Normal conception rates and litter sizes were obtained. The progeny fell into groups as follows: LL 34, YL 28, YY 24, and LY 20 piglets. The distribution, however, varied greatly within the various litters. One litter consisted merely of purebreds. The sires were successfully determined by blood group testing in $95 \%$ of the cases.

The crossbred piglets grew very significantly $(\mathrm{P}<0.001)$ faster than the purebreds. They also were more vital than the purebreds. In carcass characteristics the purebreds and crossbreds were either similar to each other or the crossbreds represented intermediate forms between the two parent races.
\end{abstract}

Purebred and crossbred piglets born in the same litters were compared with each other in crossbreeding experiments in the 1920's and 1930's (LusH et al. 1939, Roberts and CARroll 1939). The young were produced by mating sows with two boars of different breeds in the same heat period. Such races were used which made it possible to distinguish between purebred and crossbred progeny on the basis of colour. Such races were Poland China, Duroc Jersey and Yorkshire.

Now that instead of natural service sows can be inseminated artificially and the progeny identified by blood group testing, the method has become even more applicable. It can be extended to all races available, and the fact that AI allows semen to be mixed eliminates the effects of order of service and intervals between the services.

In this kind of crossbreeding experiment where the purebreds and crossbreds have the same dams and shared foetal and litter periods, the differences due to dams are reduced to a minimum. It can be expected therefore that by this method crossbreeding studies could be carried out with smaller numbers of animals than before without impairing the reliability of the results. Since 
interest in hybrid breeding is steadily increasing, there are good reasons for studying the usability of this method.

\section{Material and methods}

Pure Landrace and Yorkshire sows were inseminated with mixed semen of Landrace and Yorkshire boars. The aim was to obtain four different groups of progeny:

1) purebred Landrace (LL)

2) crossbred Yorkshire boar $\times$ Landrace sow $(\mathrm{YL})$

3) purebred Yorkshire (YY)

4) crossbred Landrace boar $\times$ Yorkshire sow (LY)

The pairs of boars were selected from animals in whose semen, according to previous experience, sperm density, motility and viability were approximately equal. The collections of semen were arranged one after the other to ensure that the age of both fractions was as similar as possible. Dilution was carried out with hen's egg dilute. The ratio of dilution was determined by the semen quality and was mostly $1: 3$ or $1: 4$. The two semen fractions were mixed together immediately after dilution. The vitality and motility of the sperm was closely observed even after a portion of the semen had been dispatched to the inseminators. The artificial inseminations took place on contract farms with three Landrace and four Yorkshire herds. A total of 21 inseminations were performed. Semen of eight Landrace and eight Yorkshire boars was used.

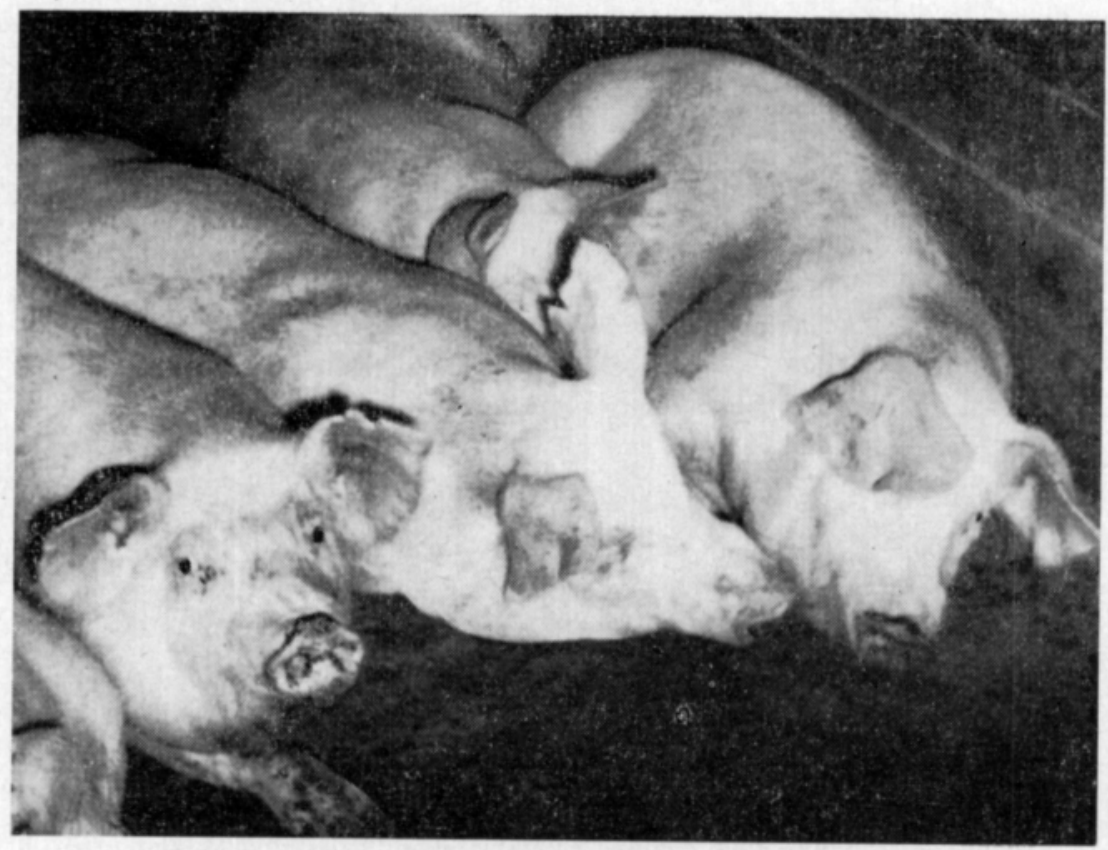

Fig. 1. Purebred (YY) and crossbred (LY) progeny of a Yorkshire sow. 
The piglets farrowed were immediately earmarked and weighed when three weeks old. A veterinary surgeon took blood samples of the progeny when they weighed $15-20 \mathrm{~kg}$ and of their parents. Blood group testing was carried out in the Blood Group Laboratory of the Federation of the Artificial Insemination Societies (Keinosiemennysyhdistysten liitto). An attempt was also made to visually distinguish between the purebreds and crossbreds by external identification marks such as the shape, position and size of ears (Fig. 1).

When the pigs weighed ca. $20 \mathrm{~kg}$, they were all taken to the same pig-rearing unit where each particular litter was reared in one pen. They were given commercial multiple feeds. Feed I with $16.0 \%$ digestible crude protein was used until the liveweight of $30 \mathrm{~kg}$ was reached and feed II with $14.0 \%$ digestible crude protein thereafter. Rationing was performed according to the average weekly litterweights using the feeding norms shown in Table 1.

Table 1. Feeding standards for the experimental pigs.

Pig weight, kg FU/pig/day

\begin{tabular}{|c|c|c|}
\hline $20.0-24.9$ & ….............................. & 1.0 \\
\hline $25.0-29.9$ & …............................... & 1.2 \\
\hline $30.0-34.9$ & ............... & 1.3 \\
\hline $35.0-39.9$ & (n..................................... & 1.5 \\
\hline $40.0-44.9$ & (n................................. & 1.7 \\
\hline $45.0-49.9$ & ….............................. & 1.9 \\
\hline $50.0-54.9$ & .................... & 2.1 \\
\hline $55.0-59.9$ & 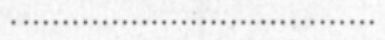 & 2.3 \\
\hline $60.0-64.9$ & (n.................................. & 2.5 \\
\hline $65.0-69.9$ & ….............................. & 2.7 \\
\hline $70.0-74.9$ & ….................... & 2.8 \\
\hline $75.0-79.9$ & 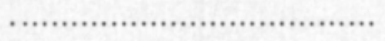 & 3.0 \\
\hline $80.0-84.9$ & 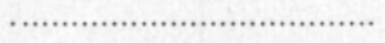 & 3.2 \\
\hline $85.0-89.9$ & 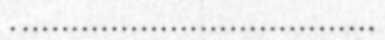 & 3.3 \\
\hline
\end{tabular}

The pigs were sent for slaughter when they reached the liveweight of $88 \mathrm{~kg}$. Dispatches were made once weekly. The pigs were weighed when sent for slaughter (liveweight) and at the slaughterhouse as cold carcasses without lard and kidneys (slaughterweight). Half-carcasses were cut according to the normal Finnish system (Uusisalmi 1969, Fig. 2).

The statistical analysis was carried out with an IBM 1130 computer. The effects of variation in initial weight, initial age and final weight upon growth during the experimental period, and the effect of carcass weight upon carcass characteristics were eliminated by least squares variance analysis (HARvey 1966) using linear regressions. The general statistical model was as follows:

$\mathrm{y}=\mathrm{a}_{0}+\mathrm{a}_{1}+\ldots+\mathrm{a}_{\mathrm{n}}+\mathrm{b}_{1} \mathrm{x}_{1}+\ldots+\mathrm{b}_{\mathrm{m}} \mathrm{x}_{\mathrm{m}}+\underline{\mathrm{e}}$

in which $\mathrm{y}=$ dependent variable, $\mathrm{a}_{0}=$ constant, $\mathrm{a}_{1} \ldots \mathrm{a}_{\mathrm{n}}=$ class variables, $b_{1} \ldots b_{m}=$ regression coefficients, $x_{1} \ldots x_{m}=$ regression variables, and $\mathrm{e}=$ normally distributed random error with the expected average of $\mathrm{O}$. The effect of sex was eliminated by pooling the data for gilts and barrows. Differences between means were tested by the Tukey's test (STEEL and Torrie $1960)$. 


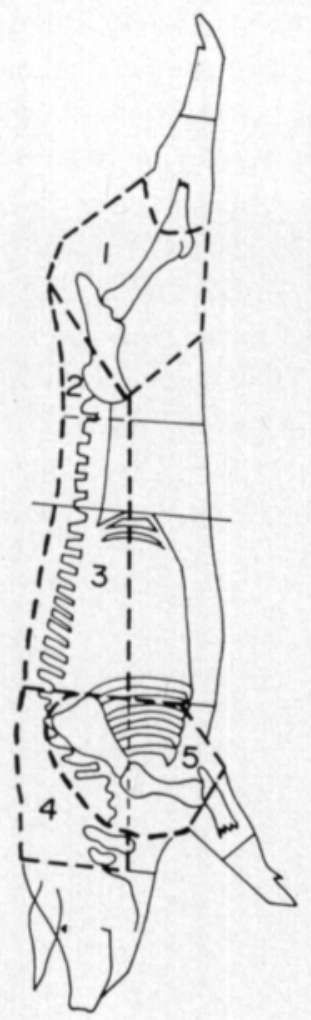

Fig. 2. Cuts of porcine carcass (Uusisaimi 1969).

The most valuable parts:

$1=$ ham

$2=$ loin

$3=$ back

$4=$ foreback

$5=$ shoulder

\section{Results}

Insemination results

After combination of the two semen fractions nothing extraordinary was noted in terms of sperm vitality and motility. The percentage of conception was 67 . The number of piglets per litter varied from 2 to 17 . The two smallest litters were omitted from the experiment which thus came to comprise 12 litters, six by Landrace sows and six by Yorkshire sows (Table 2). In these the average numbers at birth were 11.8 live piglets and 1.3 stillbirths, at the age of three weeks 9.5 piglets. The average litterweight at three weeks was $53.6 \mathrm{~kg}$.

Table 2. Distribution of purebreds and crossbreds within the litters according to blood group testing.

\begin{tabular}{|c|c|c|c|c|c|c|c|}
\hline \multirow{2}{*}{ Litter } & \multirow{2}{*}{$\begin{array}{l}\text { Herd book nos. } \\
\quad \text { of sires }\end{array}$} & \multicolumn{6}{|c|}{ Number of piglets } \\
\hline & & LL & YL & YY & LY & Unsolved & Total \\
\hline 1 & $8246+2701$ & 7 & 3 & - & - & 1 & 11 \\
\hline 2 & $8244+2250$ & 7 & 1 & - & - & - & 8 \\
\hline 3 & $8277+2431$ & 9 & 2 & - & - & - & 11 \\
\hline 4 & $8337+2774$ & 4 & 6 & - & - & - & 10 \\
\hline 5 & $8342+2001$ & 3 & 10 & - & - & - & 13 \\
\hline 6 & $8342+2351$ & 4 & 6 & - & - & - & 10 \\
\hline 7 & $8246+2701$ & - & - & 4 & 5 & 1 & 10 \\
\hline 8 & $8340+2351$ & - & - & 1 & 8 & - & 9 \\
\hline 9 & $8641+2353$ & - & - & 4 & - & 3 & 7 \\
\hline 10 & $8342+2001$ & - & - & 6 & 2 & - & 8 \\
\hline 11 & $8244+2250$ & - & - & 7 & - & - & 7 \\
\hline 12 & $8698+2773$ & - & - & 2 & 5 & 1 & 8 \\
\hline Total & & 34 & 28 & 24 & 20 & 6 & 112 \\
\hline
\end{tabular}


The distribution of purebred and crossbred piglets within the litters varied greatly (Table 2). Higher conception rate was in some cases achieved with the boar of the same race as the sow, in other cases with the different one. When on three occasions the same pair of boars were used on both Yorkshire and Landrace sows ( 1 and 7, 2 and 11, 5 and 10), a better result was in two cases

obtained with the boar of the same race. One litter consisted of purebred progeny only, and in another, purebreds only could be determined. Total distribution was as follows: LL 34, YL 28, YY 24, and LY 20 piglets.

Blood group testing was successful in identifying the sires of $94.7 \%$ of the piglets (Table 2). Visual identification on the basis of external appearance was successful in $74.3 \%$ of the cases.

Rearing results

Viability of the piglets came on trial during the rearing period due to an attack of pneumonia caused by the bacterium Pasteurella multocida. The losses in the experimental period were as follows:

\section{Purebreds Grossbreds $\begin{array}{r}\text { Paternity } \\ \text { unsolved }\end{array}$}

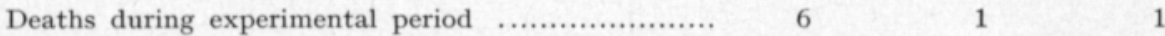

Sent for slaughter before reaching normal weight $\ldots . \quad 5 \quad-$

Excluding all those animals which succumbed to illness or were unidentified, as well as those litters (Nos. 9 and 11) which did not contain crossbreds, growth results (Table 3 ) were obtained for 41 purebreds and 47 crossbreds. The crossbreds grew significantly faster than the purebreds (difference in the experimental period $76.8 \mathrm{~g} /$ day $\left.^{* * *}\right)$. There were no weight differences at the age of three weeks nor at the start of the experiment. In the Landrace sow group the crossbred progeny increased their growth rate remarkably from the fourth week of the experiment (Fig. 3).

Both of the two groups of purebreds grew at an almost equal rate and both of the crossbred groups faster than the purebreds (Fig. 3). In the litters of the Landrace sows the difference became significant from the sixth week of the experiment; in the litters of the Yorkshire sows it was significant in the seventh and eighth week only. Expressed in weight units the difference was larger in the latter group than in the former, but due to the small number of piglets in the YY group and the relatively wide dispersion of the results within the group (Table 3 ), the statistical significance of the results remained low (Fig. 3).

It was not possible to determine the feed conversion efficiency separately for the purebreds and the crossbreds since all pigs belonging to the same litter were reared together in the same pen. An indication of this can be obtained by comparing the feed consumption of the various litters in view of the relative numbers of purebreds and crossbreds in them. The comparison reveals that on the average the crossbreds were slightly more efficient feed consumers than 


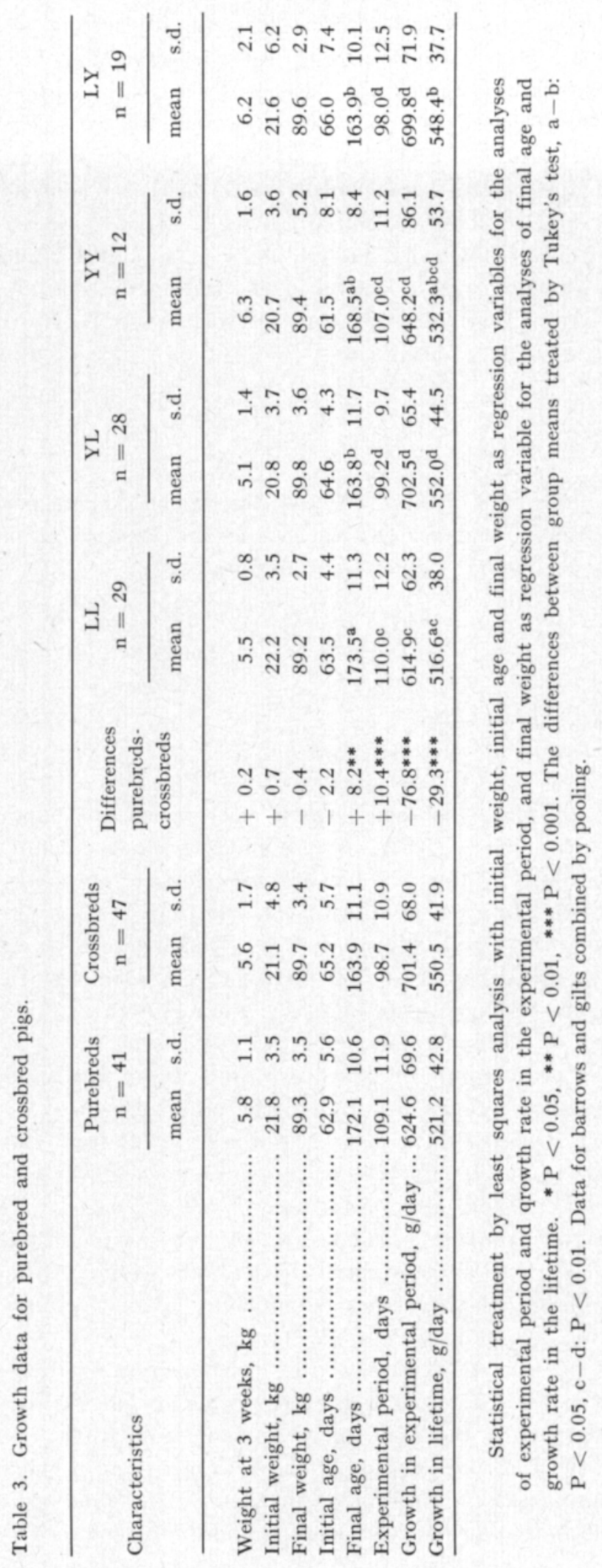




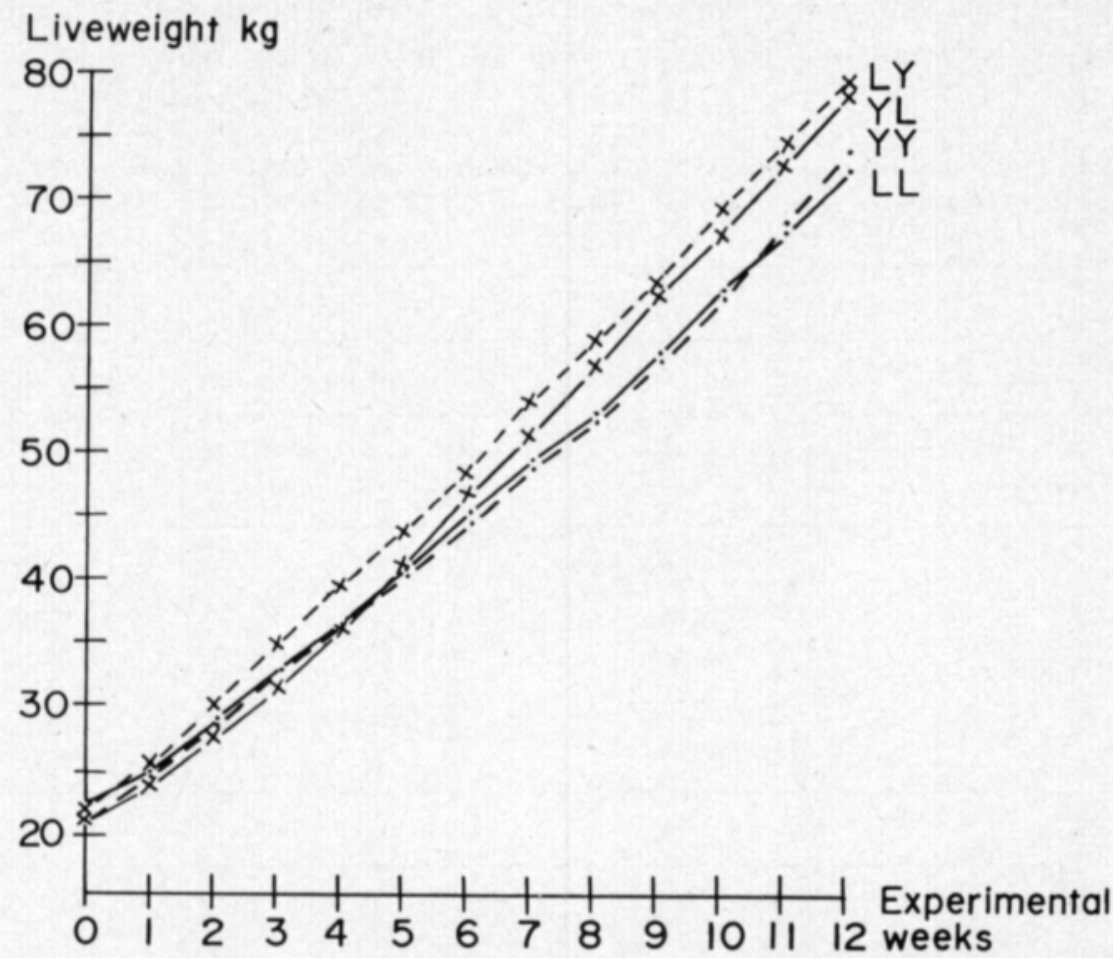

Fig. 3. Average liveweights of purebred and crossbred piglets and the significance of weight differences up to the 12 th week when the first experimental animals were submitted for slaughter.

\begin{tabular}{|c|c|c|c|c|c|c|}
\hline \multicolumn{7}{|c|}{ int } \\
\hline \multirow{2}{*}{\multicolumn{4}{|c|}{ initial weight }} & YL-LL & LY - YY & $\mathrm{LY}-\mathrm{YL}$ \\
\hline & & & & -1.4 & +0.9 & +0.8 \\
\hline \multicolumn{4}{|c|}{ 1st-week weight ... } & -1.6 & +0.7 & $+1.8^{*}$ \\
\hline 2nd- & , & - & ......................... & -1.6 & +1.6 & $+2.6^{*}$ \\
\hline 3rd- & , & , & .......... & -1.6 & +2.0 & $+3.5 * *$ \\
\hline 4 th- & - & , & ...... & -0.7 & +2.8 & $+3.5^{*}$ \\
\hline 5th- & , & , & 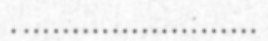 & +0.4 & +3.7 & +2.8 \\
\hline 6 th- & , & , & $\ldots$ & $+1.5^{* *}$ & +4.3 & +1.7 \\
\hline 7 th- & , & , & ..... & $+1.8 * *$ & $+5.4^{*}$ & +2.9 \\
\hline 8th- & , & , & $\ldots$ & $+3.7 * *$ & $+6.2^{*}$ & +1.7 \\
\hline 9th- & , & , & ........... & $+4.3^{* *}$ & +5.9 & +0.7 \\
\hline 10th- & , & , & ..... & $+4.4 * *$ & +6.5 & +1.9 \\
\hline 11th- & , & , & 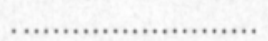 & $+5.4^{* *}$ & +6.2 & +1.8 \\
\hline 12 th- & , & , & 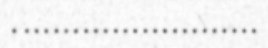 & $+5.9 * *$ & +5.3 & +1.0 \\
\hline
\end{tabular}


the purebreds (Table 4). The average feed efficiency of all the test animals during the experimental period was $3.21 \mathrm{FU} / \mathrm{kg}$ of weight gain.

Table 4. Feed conversion efficiency of pigs of various litters, a) litters with more than $50 \%$ purebreds, b) litters with more than $50 \%$ crossbreds.

\begin{tabular}{|c|c|c|c|c|c|}
\hline \multicolumn{3}{|c|}{ a } & \multicolumn{3}{|c|}{ b } \\
\hline \multicolumn{2}{|c|}{ No. of pigs } & \multirow{2}{*}{$\begin{array}{c}\mathrm{FU} / \mathrm{kg} \text { of } \\
\text { growth }\end{array}$} & \multicolumn{2}{|c|}{ No. of pigs } & \multirow{2}{*}{$\begin{array}{l}\mathrm{FU} / \mathrm{kg} \text { of } \\
\text { growth }\end{array}$} \\
\hline $\begin{array}{l}\text { pure- } \\
\text { breds }\end{array}$ & $\begin{array}{l}\text { cross- } \\
\text { breds }\end{array}$ & & $\begin{array}{l}\text { pure- } \\
\text { breds }\end{array}$ & $\begin{array}{l}\text { cross- } \\
\text { breds }\end{array}$ & \\
\hline 9 & 2 & 3.90 & 1 & 8 & 2.94 \\
\hline 7 & 1 & 3.39 & 4 & 6 & 2.98 \\
\hline 6 & 2 & 3.36 & 4 & 5 & 3.05 \\
\hline 7 & 3 & 3.13 & 3 & 10 & 3.12 \\
\hline- & - & - & 4 & 6 & 3.14 \\
\hline- & - & - & 2 & 5 & 3.16 \\
\hline 29 & 8 & 3.45 & 18 & 40 & 3.07 \\
\hline
\end{tabular}

\section{Carcass characteristics}

Carcass section measurements and lean cuts analyses were obtained for 72 animals. Of these 34 were purebreds and 38 crossbreds (Table 5 ). The table shows that in all groups the carcass characteristics were quite similar. The only statistically significant differences between purebreds and crossbreds were found in weight distribution between the fore- and rear part of the carcass and in the fat + skin fraction of the ham-loin section. The amount of meat + bone produced per day was significantly larger for the crossbreds (94.1 g/animal/day) than for the purebreds $(\mathbf{8 8 . 5} \mathrm{g})$ but the difference was a result of faster growth rather than an indication of a larger amount of meat + bone in the carcass. Differences were found between the purebred groups in the amount of meat + bone in the back section as well as in side length. The crossbreds inherited these characteristics in intermediate form.

\section{Discussion}

The use of mixed semen of boars of different races in crossbreeding experiments proved practicable in the sense that it was possible to mix the semen without complications and to achieve normal conception rates and litter sizes. On the other hand, the great variability of the distribution of purebreds and crossbreds within the litters was a factor reducing the practicability of this method as compared with normal crossbreeding experiments with separate litters. The same difficulty emerged, even more clearly, in the earlier investigations. In the work of RoBERTS and CARRoll (1939) nearly $40 \%$ of the litters 


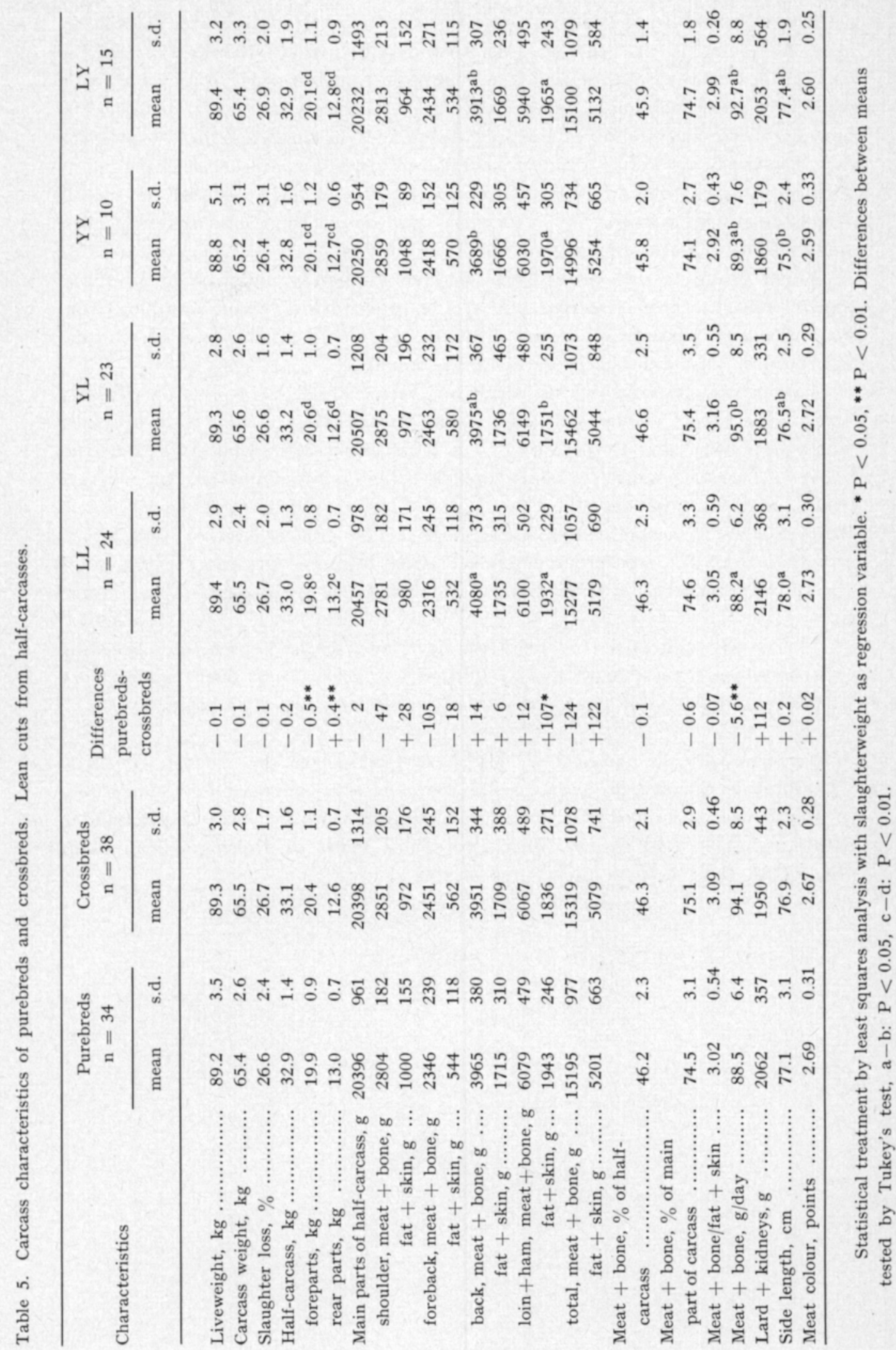


consisted of progeny of one boar only, this being in half of the cases the first in order of service, in the other half the second. LusH et al. (1939) arrived at the conclusion that the order of service was unimportant in regard to the conception result, whereas the main factor was the fertility of individual boars. The present study also indicates possible differences in boar fertility despite the fact that the boars were carefully selected and tested for uniform semen quality. This requirement of uniformity, however, appears to have reduced the effects of this detrimental factor, for in no more than one of the twelve litters studied were all the piglets offspring of one boar only.

Blood group testing proved an effective method of indentification of the piglets with the only reservation that the procedure of blood sampling from very young piglets was somewhat difficult. Judgment on the basis of external appearance only did not prove accurate enough.

The animal material in this study was rather small. This was particularly true of the litters of the Yorkshire sows. Nevertheless results were obtained which were very similar to those of e.g. SKÅRMAN (1965), who studied crosses between Landrace and Yorkshire breeds using a large material of separate litters, and to those described by GLODEK (1970) and LAUPRECHT (1957) in their reviews of crossbreeding experiments. The greater vitality and higher growth rate of the crossbreds emerged clearly from the present experiment as also did the similarity or the intermediate inheritance of the carcass characteristics.

This study indicates therefore that if mixed semen is used, crossbreeding experiments are possible with very limited animal material even though very variable proportions of purebred and crossbred progeny are obtained.

A cknowledgements. My best thanks are due to the Artificial Insemination Society of Salpausselkä (Salpausselän keinosiemennysyhdistys), to the Research Foundation for Agricultural Machinery (Maatalouskoneiden tutkimussäätiö), and to the Meat Processing Plant of Helsingin Kauppiaat OY for all their help in the course of this study. 


\title{
REFERENCES
}

GLODEK, P. 1970. Zuchtverfahren zur Ausnutzung der Heterosis und ihre Anwendung in der Schweinezucht. II. Ergebnisse aus Schweinezuchtversuchen. Z. Tierz. Zücht.biol. $86: 273-288$.

HARVEY, W. R. 1966. Least-squares analysis of data with unequal subclass numbers. ARS 20-8. Agric. Res. Service, U.S. Dept. of Agric. 157 p.

LAUPRECHT, E. 1957. Uber das Verhalten der Nachkommen aus Paarungen verschiedener Rassen des Schweines. Ein Beitrag zur Heterosisfrage. Z. Tierz. Zücht.biol. 70: 57-76.

Lush, J. L., Shearer, P. S. \& Culbertson, C. C. 1939. Crossbreeding hogs for pork production. Ia. Agric. Exp. Sta. Bull. 380: 82-116.

Roberts, E. \& CARroll, W. E. 1939. A study of hybrid vigor in a cross between Poland China and Duroc Jersey swine. J. Agric. Res. 59: 847-854.

Sкג̊rman, S. 1965. Crossbreeding experiments with swine. Lantbrukshögsk., Ann. 31: 3-92.

Stekl, R. G. D. \& Torrie, J. H. 1960. Principles and procedures of statistics. 481 p. New York.

UUsisalmi, U. 1969. Vorläufige Ergebnisse über das Messen der Schlachteigenschaften beim Schwein. J. Scient. Agric. Soc. Finl. 41:50-59.

\section{SElostus}

\section{Eri rotuisten karjujen siemenseoksella suoritettu risteytyskoe}

\author{
Elsi Etrala \\ Maatalouden tutkimuskeskus, Kotieläinhoidon tutkimuslaitos, Tikkurila
}

Maatiais- ja yorkshirerotuisten ( $\mathrm{M}$ ja $\mathrm{Y}$ ) karjujen siemenseoksella siemennettiin maatiaisja yorkshire-emakoita ja veriryhmämäärityksellä tunnistettiin pahnueiden puhdasrotuiset ja risteytysjälkeläiset. Karjupareiksi valittiin sperman laadun suhteen mahdollisimman samankaltaiset yksilöt.

Laimennettujen sperma-annosten yhdistäminen ei vaikuttanut haitallisesti siittiöiden elävyyteen tai liikkeisiin. Tiinehtyminen ja pahnuekoko olivat myōs normaaleja. Jälkeläisten jakautuminen eri ryhmiin oli sèuraava: MM 34 kpl, YM 28 kpl, YY 24 kpl ja MY 20 kpl. Jakautuminen eri pahnueissa oli kuitenkin varsin vaihteleva. Yhdessä pahnueessa oli pelkästään puhdasrotuisia eläimiä. Porsaiden isät kyettiin mäårittämään veriryhmämäärityksellä n. 95 $\%:$ sesti.

Risteytyseläimet kasvoivat merkitsevästi $(\mathrm{P}<0.001)$ nopeammin kuin puhdasrotuiset. Ne olivat myös puhdasrotuisia elinvoimaisempia. Ruho-ominaisuuksiltaan puhdasrotuiset ja risteytysjälkeläiset olivat hyvin samankaltaisia tai risteytyseläimet edustivat rotujen välimuotoa.

Tutkimuksen perusteella näyttää siltã, että seossiementä käyttäen voidaan varsin pienellä aineistolla selvittää eri rotujen risteytystuloksia siitäkin huolimatta, että puhdasrotuisten ja risteytysjälkeläisten lukumäärät pahnueissa vaihtelevat. 